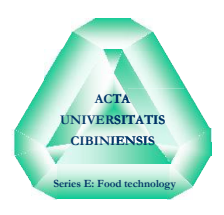

\title{
THE INFLUENCE OF MICROBIOLOGICAL QUALITY OF WATER RESOURCES IN DAIRY GOAT FARMS
}

\author{
Ramona Maria IANCU ${ }^{1}$ \\ PhD Fellow, SOP HRD/159/1.5/s/133675 Project, Lucian Blaga University \\ from Sibiu, Romania
}

\begin{abstract}
Water pollution is an essential component for the farmers in managing their agriculture fams. In almost all cases, without the chemical and microbiological analysis of water samples, the effect is damaging the animals and also the consumers. The study was carried out in Sibiu region of Romania, along Hârtibaciu River, and includes four farms, averaging 250 goats with different production system. Difficulties in ensuring quality milk, derived from various sources of contamination, the quality of water is directly depended on the maintenance of water suply. The foreign substances or microorganisms sometimes don't affect the appearance or taste of the water, but can influence the health of animals and of course the quality of dairy products. This study was made to analyse the microbiological quality of water resources of the farmers, knowing that this is a major factor which influence the guality of the milk. The bacteriological tests were made onto Agar medium culture in petri dishes and were incubated at $37^{\circ} \mathrm{C}$ for $48 \mathrm{~h}$. Based on the microbiologicaly tests of the Hârtibaciu River resource, we could analyse the quality of the milk, too. The results of this study was presented and discused with the farmers and it was the starting point for them in changing their breeding technology, looking forward to improve their dairy production. A better quality of goat milk will be the main purpose of this study knowing that the farmers successed in their business.
\end{abstract}

Keywords: water, goat, milk, microbiologic, quality, production system

\section{INTRODUCTION}

The quality of water regarding the microbiological indices can have economic impact for farmers (Collins et al., 2007) through its effects on crop production and animal breeding (performance in milk production and weight

${ }^{1}$ Corresponding author. Mailing address: University "Lucian Blaga" of Sibiu, Faculty of Agricultural Sciences, Food Industry and Environmental Protection, Str. I. Raţiu 7-9, 550012 Sibiu, Romania. Phone: 0040/269/211338. Fax: 0040269212558. E-mail address: ramy11us@yahoo.com 
gain). (Heathwaite et al., 2005b) (Pickett et al., 2001) The main sources of water pollution are defined as , any discernable, confined and discrete conveyance, including but not limited to, any pipe, ditch, channel...not including agricultural storm water and return flow from irrigated agriculture" (Edwards et al., 2008).

Indeed, water quality plays for the farmers an important role in animal performance, nutrition and health (Davies-Colley et al., 2004) In recent years, efforts to improve water quality were focused on these sources (Steyaert et al., 2007) (Lengyel, 2012), because livestock need access to large quantity of clean water every day (Popa et al., 2014)

It is necessary to ascertain if the activity of small farmers can compete favorably in the production of goat milk in good hygienic conditions, monitoring and analyzing the water samples taken from farmer's environment. (Monaghan et al., 2004) Without microbiological analysis of water, it would not be possible to determine the status and safety of drinking milk (Smith, 1993), which is so essential to establish the need and adequacy of treatment, and to safeguard human health (Devendra, 1982)

This study will serve as an educational tool for the farmers, to change their breeding technology, looking forward to improve their dairy production. (Tiţa, 2003)

\section{MATERIALS AND METHODS}

The study was carried out in Sibiu depression, along the Hârtibaciu River; the Hârtibaciu meadow has two clearly differentiated sectors, the sector upstream of Sibiu: Sibiu-Agnita and Agnita-Retiş. The studied farms are located along the Hârtibaciu River, averaging 250 goats with different production system. Water sample were collected from 4 different locations along Hârtibaciu River, as Figure 1 shows.

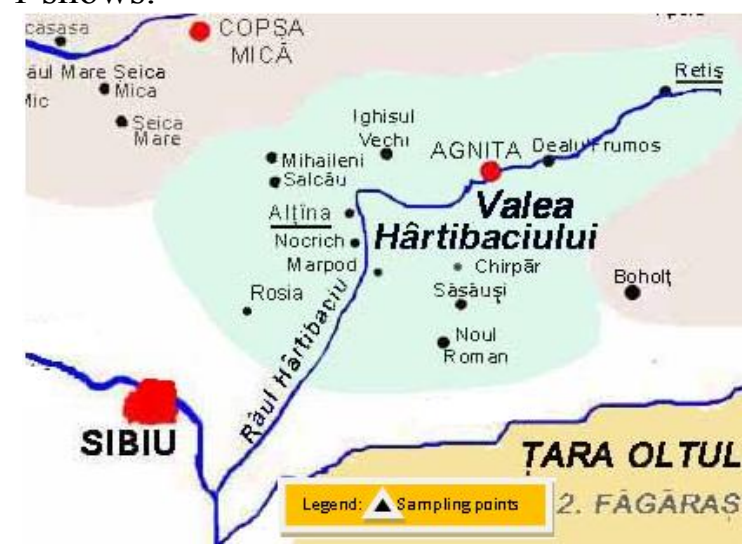

Figure 1 Hârtibaciu River in Sibiu Depression with sampling stations 
The water samples were collected during 2014, in 4 different points, in sterile bottles for microbiological tests according with ISO SR EN 17.025/2005 (General requirements for the competence of testing and calibration) and sent to Microbiology and Biotechnology Research Department (part of Lucian Blaga University, Sibiu). The samples were kept at $4^{\circ} \mathrm{C}$ during transport; otherwise the determination of microorganisms would not have been relevant. Analysis methods used to determine microbiologicaly quality for water was made as follow: from the sanitary point of view and public health, the water samples were analyzed for total coliforms, total fecal coliforms, Enterococcus and E. coli, according with the current Romanian legislation and normative (Order 1146/2002).

Because water quality has an impact upon milk quality and its characteristics (Wilcock et al., 2006), we proceeded to analyze the microbiological quality of goat milk from farms, too. At the end of the study, it was made a correlation between water and milk quality in every farm involved. The milk analyzes were conducted in accordance with: SR EN ISO 4833-2003 for bacteria total number, STAS ISO 4831-92/2006 for coliforms, SR ISO 725196/2005 for Escherichia coli, SR ISO 7954-2001 for yeasts and moulds. In order to provide a characterization of milk quality, a total of 16 samples (4 sample x 4 farms in one month) have been collected during June 2014.

\section{RESULTS AND DISCUSSIONS}

\section{The microbial quality of Hârtibaciu River}

The results of our study have shown a number of interesting points regarding the sanitary parameters of Hârtibaciu River water quality. Controlling the water quality is vitally for the farmers (Abida et al., 2008), especially if they are concerned about: milk production, feed consumption which can lead to losses of body weight. This is why, farmers have to consider microorganisms in direct relation to livestock water quality. (Cumming et al., 2006)

To know the likelihood of contamination by organisms, we have to analyze the coliform concentration. (Eleria, 2002) It is well known that diseases such as dysentery, gastroenteritis, and hepatitis A (Ashbolt, 2004; Donovan, 2008) are cause by the presence of these coliforms, especially of fecal coliforms (which indicate the potential contamination). The contamination is also made by the digestion of food.

The primary water's health indicators are the coliform, found in different forms as E.coli, fecal coliform, Enterobacter. (Medema et al., 1997) In our study, the minimum value of total coliform have been registered by Farm no. 2 with 5400 germs $/ 100 \mathrm{~cm}^{3}$ water, followed by Farm no 4 with 7200 germs $/ 100 \mathrm{~cm}^{3}$ water (figure 2). 


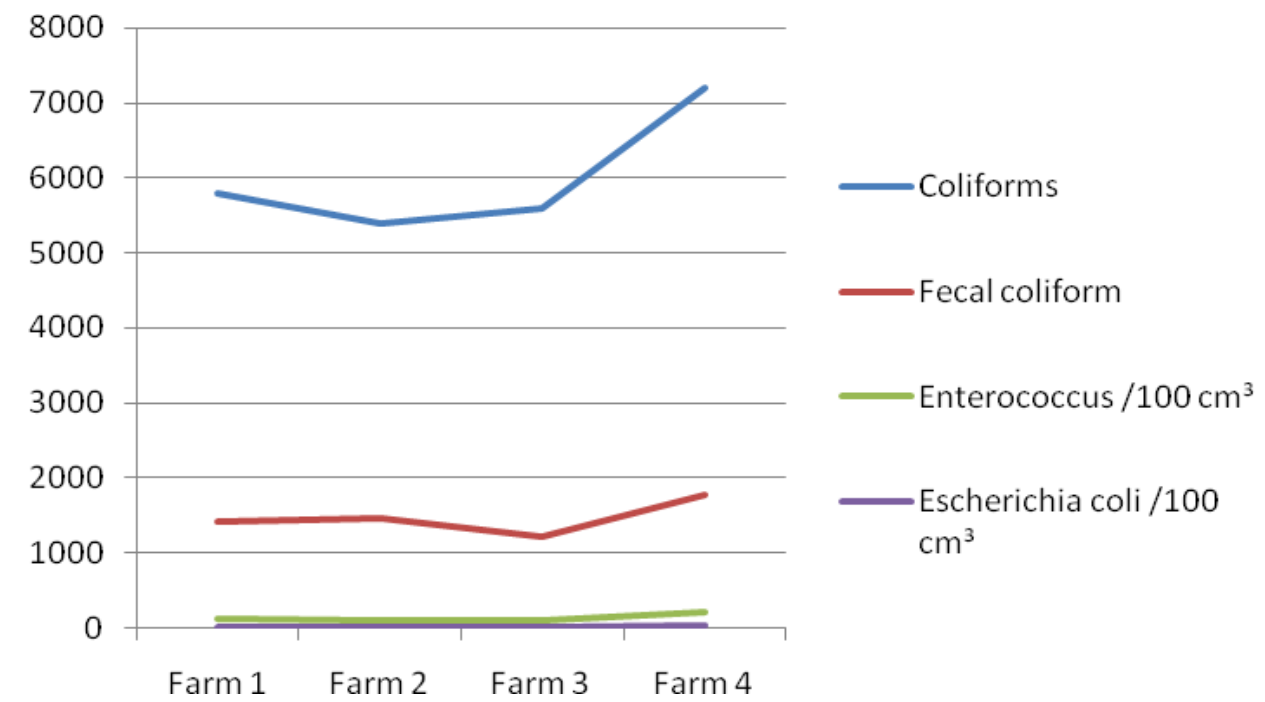

Figure 2 The microbial quality of Hârtibaciu River

Following the analyzes regarding the total number of faecal coliforms we can say that the minimum contamination was recorded in farm no. 3 with 1218 germs $/ 100 \mathrm{~cm}^{3}$ water, unlike the farm no 4 , where the number was 1784 germs $/ 100 \mathrm{~cm}^{3}$ water (figure 2).

E. coli and Enterococcus has been the foremost indicator of fecal contamination in water quality monitoring for many decades. (Patoli et al., 2010) E. coli has also been shown to be a significant reservoir of genes coding for antimicrobial drug resistance and therefore is a useful indicator for resistance in bacterial communities. (Bucknell et al., 1997; Rasmussen et al., 2003)

The number of coliform bacteria, respectively Enterococcus (afferent figure 2 ) is increasing substantially in the farm no.4, values reaching between 102 and $218 / 100 \mathrm{~cm}^{3}$ per sample because of the production system adopted by the farmer. E.coli reaches values of $21 / 100 \mathrm{~cm}^{3}$ per sample at the Farm no. 3 and increases to $32 / 100 \mathrm{~cm}^{3}$ per sample at the Farm no. 4 .

\section{Microbial analysis and quality control of goat milk collected from studied farms}

Milk quality vary in their tolerance to diffrent water quality parameters. Common problems with drinking and using quality water can be identified by testing for the parameters in milk such as: total number of bacteria, coliforms, Escherichia coli and yeasts and moulds. A clean water supply is essential to 
minimize contamination. From the milk recording data, the results are presented in figure 3.

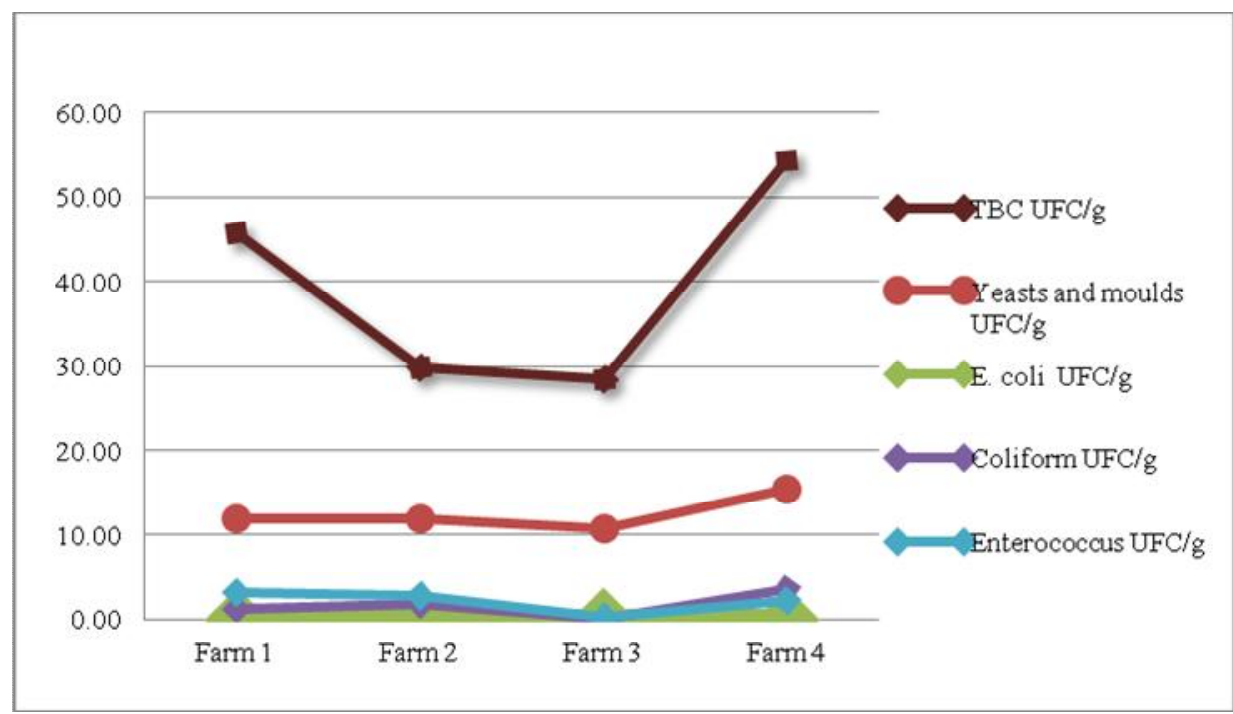

Figure 3 Microbial analysis of goat milk collected from studied farms

For the milk samples there have been recorded a TBC (total bacteria count) values ranging between $28.54 \mathrm{ufc} / \mathrm{ml}$ (Farm 3) and $54.30 \mathrm{ufc} / \mathrm{ml}$ (Farm 4), while the milk samples regarding the yeasts and mouls ranged between 10.70 ufc/ml (Farm 3) and $15.50 \mathrm{ufc} / \mathrm{ml}$ (Farm 4).

Out of all coliforms and Enteroccocus having been analyzed in the milk sample collected; it is obvious that also in this case the results are extremelly high at Farm 4 and very low at Farm 3. Escherichia coli has not be identified in the milk sample collected.

\section{CONCLUSIONS}

After the study was made it seems that Hârtibaciu River has microbiological values which frame it in the second water quality Class (coliforms-less than $10000 \mathrm{ufc} / \mathrm{ml}$ water).

The Hârtibaciu River is characterized by a good water resource for farms, regarding the water sanitary parameters.

The elements that define human involvement lead to a consider contamination of the Farm 4. Based on the number of samples taken, it appears that the highest environmental contamination occurred in the extensive production system (Farm 4) in comparison to the other systems. A possible source of contamination can be the farmer hands and thus emphasize the importance of personal hygiene during water transport. 
But, the main conclusion can be written as: applying rules of proper hygiene can lead to a better health status of the animals, a good milk production itself, as we were happy to see at the Farm 3 (semi-intensive farm), which recorded the lowest values of microbiological indices.

The consumer consider if the tastes of milk is good, they will accept it as a good quality drinking milk. If the milk contain excessive amounts of harmful substances, this may be dangerous, causing health effects for consumers if the water analysis weren't made.The correlation between water resources and milk quality in every farm involved was made to assess the impact of human interventions on the nutritional status of consumer over the Hartibaciu River region. The results of our work demonstrate that the quality of milk is extremelly depended on the quality of water and the way how the rules of proper hygiene are followed. One of the farmers didn't know or understand this correlation; because of that and because the milk quality does not fulfill the minimum quality set standards, the production of milk can be rejected from the collector. This can lead to economical loss to the farmer.

In order to reduce human contamination the implementation of educational programs is recommended so that the negative impact of man, on the natural sources of water, to be minimal.

\section{ACKNOWLEDGEMENTS}

This paper is supported by the Sectoral Operational Programme Human Resources Development (SOP HRD), financed from the European Social Fund and by the Romanian Government under the contract number POSDRU/159/1.5/S/133675.

\section{REFERENCES}

1. Abida, B. \& Harikrishna, M. (2008). Study on the Quality of Water in Some Streams of Cauvery River. E-Journal of Chemistry, 5(2), 377-384.

2. Ashbolt, N.J. (2004). Microbial contamination of drinking water and disease outcomes in developing regions. Toxicology, 198, 229-238.

3. Bucknell, D.G., Gasser, R.B., Irving, A. \& Whithear, K. (1997). Antimicrobial resistance in Salmonella and Escherichia coli isolated from horses. Austrian Veterinary Journal, 75, 355-356.

4. Collins, R., McLeod, M., Hedley, M.J., Donnison, A., Close, M., Hanley, J., Horne, D., Ross, C., Davies-Colley, R., Bagshaw, C. \& Matthews L. (2007). Best management practices to mitigate faecal contamination by livestock of New Zealand waters. New Zealand Journal of Agricultural Research, 50, 267-278. 
5. Cumming, G.S., Cumming, D.H. \& Redman, C.L. (2006). Scale mismatches in social-ecological systems: causes, consequences, and solutions. Ecol Soc, 11, 14.

6. Davies-Colley, R.J., Nagels, J.W., Smith, R.A., Young, R.G. \& Phillips C.J. (2004). Water quality impact of a dairy cow herd crossing a stream. New Zealand Journal of Agricultural Research, 38, 569-576.

7. Devendra, C. (1982). Potential of sheep and goats in less developed countries. In: Development Digest, 22(1), 35-49.

8. Donovan, E., Unice, K., Roberts, J.D., Harris, M. \& Finley B. (2008). Risk of gastrointestinal disease associated with exposure to pathogens in the water of the lower Passaic River. Applied Environmental Microbioly, 74, 994-1003.

9. Edwards, A.C. \& Withers P.J.A. (2008). Transport and delivery of suspended solids, nitrogen and phosphorus from various sources to freshwaters in the UK. Journal of Hydrology, 350, 144-153.

10. Eleria, A.L. (2002). Forecasting Fecal Coliform Bacteria in the Charles River Basin. Master's Thesis, Tufts University, Medford, Massachusetts, 5,38 .

11. Lengyel, E., Oprean, L., Tita, O., Iancu, R. \& Iancu M. (2012). Biodiversity of the microorganisms existing in the Salt Lakes at Ocna Sibiului (Romania) and Chott El Jerid (Tunisia), Transylvanian Review of Systematical and Ecological Research, The Wetlands Diversity, 2, 41-48.

12. Heathwaite, A.L., Quinn, P.F. \& Hewett C.J.M. (2005b). Modeling and managing critical source areas of diffuse pollution from agricultural land using flow connectivity simulation. Journal of Hydrology, 204, 446-461.

13. Medema, G.J., Bahar, M. \& Schets F.M. (1997). Survival of Cryptosporidium parvum, Escherichia coli, faecal enterococci and Clostridium perfrigens in river water: influence of temperature and autochthonous microorganisms. Water Science Technology, 35(11), 249252.

14. Monaghan, R.M., Thorrold, B.S., Smeaton, D., Hyslop, M.G., Stevens, D.R., De Klein, C.A.M., Smith, L.C. \& Drewry J.J. (2004). A desktop evaluation of the environmental and economic performance of model dairy farming systems within four New Zealand catchments. Proceedings of the New Zealand Grassland Association, 66, 57-67.

15. Patoli A.A., Patoli B.B., Mehraj V. (2010). High prelevance of multi-drug resistant Escherichia coli in drinking water samples from Hyderabad. Gomal Journal of Medical Sciences, 8(1), pp 23-26.

16. Pickett, S.T.A., Cadenasso, M.L., Grove, J.M., Nilon, C.H., Pouyat, R.V., Zipperer, W.C. \& Costanza R. (2001). Urban ecological systems: linking 
terrestrial ecological, physical, and socioeconomic components of metropolitan areas. Annual Review Ecological System, 32, 127-57.

17. Popa, I.R., Tiţa, M.A., Oprean, L, Iancu, R., Lengyel, E. \& Frum A. (2014). Microbiological characteristics of sheep and cow milk from Cristian farm, Romania, Versita, Acta Universitatis Cibiniensis, Serie E: Food Technology, 53(1), 77-84.

18. Rasmussen, P.P. \& Ziegler A.C. (2003). Comparison and Continuous Estimates of Fecal Coliform and Escherichia Coli Bacteria in Selected Kansas Streams May 1999 Through April 2002. U.S. Geological Survey Water Resources Investigations Report OS4056, Lawrence, Kansas, 80.

19. Smith, C.M., Wilcock, R.J., Vant W.N. \& Cooper A.B. (1993). Towards Sustainable Agriculture: Freshwater Quality in New Zealand and the Influence of Agriculture. NIWA ecosystems report for MAF Policy and Ministry for the Environment.

20. Steyaert, P. \& Ollivier G. (2007). How ecological assumptions frame technical and social change. Ecology and Society., 12, 1-18.

21. Tiţa, M.A. \& Blaga C.A. (2013). The role of computer assisted instruction in teaching the topic: Milk and milk products in public alimentation, International journal of marketing \& human resource management, 4(2), 6-9.

22. Tiţa, M., Tiţa, O. \& Oprean L. (2003). The additives behavior in the milk industry and the role of the experimental results in the students' education, $2^{\text {nd }}$ Balkan Region Conference on Engineering Education, Bridges for Co-operation in Engineering Education, Sibiu, Romania, 234-236.

23. Wilcock, R.J., Monaghan, R.M., Quinn, J.M. \& Campbell A.M., Thorrold B.S., Duncan M.J., McGowan A.W., Betteridge K. (2006). Land use impacts and water quality targets in the intensive dairying catchment of the Toenepi Stream, New Zealand. New Zealand Journal of Marine and Freshwater Research, 40, 123-140. 